\title{
Evaluation of Different Species of Pleurotus for Maximum Yield in Different Seasons on Paddy Straw under Temperate Conditions of Kashmir Valley
}

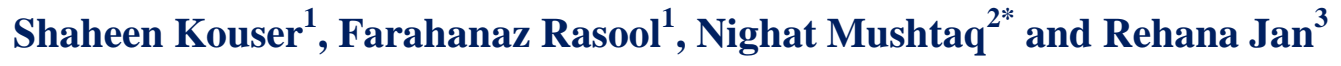 \\ ${ }^{1}$ Division of Plant Pathology, ${ }^{2}$ Division of Vegetable Sciences, ${ }^{3}$ Division of Soil Science, \\ SKUAST-K Shalimar, India \\ *Corresponding author
}

\section{A B S T R A C T}

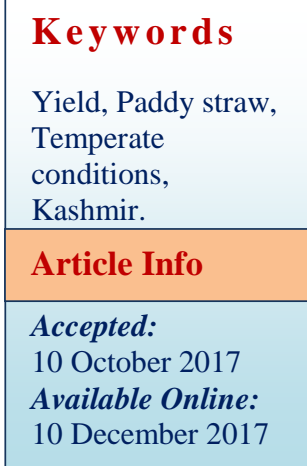

Six species of dhingri mushroom were evaluated for their yield potential and other quality characters on paddy straw substrate in three different growing seasons viz., spring, summer and autumn with temperatures during growing seasons ranging from $18-25^{\circ} \mathrm{C}, 30-35^{\circ} \mathrm{C}$ and $15-20^{\circ} \mathrm{C}$ respectively. All the six test species produced crop in all seasons but with significantly varied yield. The maximum yield was produced by local species, $P$. ulmarius and the minimum by $P$. sajor caju. Maximum yield of (36.94 kg qt ${ }^{-1}$ substrate) was recorded in autumn season and minimum (30.19 $\mathrm{kg} \mathrm{qt}^{-1}$ substrate) in summer season. Species $P$. sajor caju produced maximum crop (48.39 $\mathrm{kgqt}^{-1}$ substrate) in summer season. Maximum no. of fruit body per $\mathrm{kg}$ of mushroom (122.60) was recorded in $P$. petalloides and the average weight of single fruit body was more $(8.41 \mathrm{~g})$ in P.sajorcaju and less $(3.66 \mathrm{~g})$ in $P$. petalloides.

\section{Introduction}

Mushrooms are regarded as important food items and their usage is being increased day by day because of their significant role in human health, nutrition and disease. Mushrooms of Pleurotus spp. are commonly known as oyster mushrooms and globally occupy the second position among cultivated edible mushrooms due to their nutritional and medicinal values (Khan et al., 2008).The environmental factor is very important for the production of oyster mushrooms. Various mushrooms are known to be sensitive to the climatic conditions (Van Peer et al., 2009). The major environmental factors like temperature, humidity, fresh air and compact materials affect the mushroom production. Pleurotus spp. grows in wide range of temperature $\left(15-30{ }^{0} \mathrm{C}\right)$ which also varies from species to species (Sarker et al., 2008). Bano and Rajarathnam (1982) observed maximum yield of oyster mushroom (Pleurotus sajor-caju) when the temperature was nearly $20-26^{\circ} \mathrm{C}$ and relative humidity 70 $90 \%$. A fairly good yield can be obtained up to $30^{\circ} \mathrm{C}$. Production of $P$. fossulatus prefers $20 \pm 1^{\circ} \mathrm{C}$ but $P$. eous prefers $21-35^{\circ} \mathrm{C}$ and humidity of 65 to $100 \%$. Kong (2004) reported that $P$. ostreatus, $P$. florida, $P$. sajorcaju reach their optimum growth at $25^{\circ} \mathrm{C}$. In Kashmir, oyster mushrooms are most popular 
for their different species Pleurotus ulmarius, $P$. florida and $P$. sajor-caju and are commercially cultivated by using sawdust and/or rice straw as main substrate (Amin et al., 2007). But the productions of these mushrooms are not economically beneficial in every season.

The environmental variation is supposed to be the main cause behind this problem. But the performances of these species of oyster mushroom have not yet properly been investigated in the climatic conditions of different seasons. Therefore the present study was undertaken to identify the specific season or cultivation time for the different species of oyster mushroom.

\section{Materials and Methods}

A study was conducted to evaluate the influence of seasonal variation on yield of dhingri mushroom under temperate conditions of Kashmir. A well-ventilated room with a cemented floor and wall was used as cropping room. Various species of Pleurotus i.e. Pleurotus sajor-caju, Pleurotus flabellatus, Pleurotus florida, Pleurotus petaloides, Pleurotus ulmarius and P. fossilatus were evaluated using paddy straw as a substrate. Paddy straw was soaked in water for $18 \mathrm{~h}$. Layering method of spawning @ 4\% by wet weight basis was followed.

The spawned substrate was filled in polypropylene bags $\left(45 \times 30 \mathrm{~cm}^{2}\right)$. A unit of 2 $\mathrm{kg}$ of dry straw was used for each treatment and $500 \mathrm{~g}$ of dry straw was taken for each replication. The moisture content of the straw at the time of spawning was kept around 72$75 \%$. The filled bags were incubated in a dark room at a temperature ranging between 24$30^{\circ} \mathrm{C}$ where $90 \%$ relative humidity was maintained till the spawn run was complete. Observations on parameters viz., weight of a single fruiting body, average number of fruiting bodies and yield per $\mathrm{kg}$ of dry substrate was recorded in different seasons.

\section{Results and Discussion}

All the species of Pleurotus performed well in terms of yield and other quality characters. Maximum yield (38.62 $\mathrm{kg} \mathrm{qt}^{-1}$ dry substrate) was produced by local species, P. ulmarius which differ significantly from other species followed by $P$. fossilatus $\left(38.45 \mathrm{~kg} \mathrm{qt}^{-1}\right.$ dry substrate) and the minimum (28.14 $\mathrm{kg} \mathrm{qt}^{-1}$ substrate) by $P$. sajor caju. However, $P$. fossilatus and P. flabellatus with 38.45 and $36.02 \mathrm{~kg}$ mushroom per quintal dry substrate respectively were identical with $P$. ulmarius. Competitor moulds attack (Coprinus sp., Aspergillus niger, Penecillium sp., Sclerotium rolfsii etc., and insects infestation in the beds of $P$. sajor caju resulted in poor growth of mycelium which contributed negatively towards spawn run and yield. Maximum yield of (36.94 kg qt ${ }^{-1}$ substrate) was recorded in autumn season and minimum (30.19 $\mathrm{kg} \mathrm{qt}^{-1}$ substrate) in summer season.

However, mean yield of $\left(36.51 \mathrm{~kg} \mathrm{qt^{-1 }}\right.$ substrate) in spring season was identical with that of autumn season. There were significant interaction with season and species. Species P. sajor caju produced maximum crop (48.39 $\mathrm{kgqt}^{-1}$ substrate) in summer season and can be utilized for commercial cultivation in summer season in valley. $P$. ulmarius produced maximum crop both in spring and autumn season and can be best utilized in lower temperature belts and in most period of the year. Maximum no. of fruit body per $\mathrm{kg}$ of mushroom (286.0) was recorded in $P$. petalloides and minimum (122.60) by $P$. sajor caju. $P$. flabellatus, $P$. fossilatus and $P$. ulmarius recorded statistically identical number of fruit bodies per kg mushroom with $P$. sajor caju. Average weight of single fruit body was more $(8.41 \mathrm{~g})$ in $P$. sajorcaju and less (3.66g) in P. petalloides (Table 1). 
Table.1 Identification of different species of Pleurotus for maximum yield in different seasons on paddy straw

\begin{tabular}{|c|c|c|c|c|}
\hline \multirow{2}{*}{ Species } & \multicolumn{4}{|c|}{ Yield of dhingri mushroom $\mathbf{q t}^{\mathbf{1}}$ dry substance $^{*}$} \\
\cline { 2 - 5 } & Spring & Summer & Autumn & Mean \\
\hline P. petaloides & 35.68 & 19.04 & 42.47 & $32.39 \mathrm{c}$ \\
\hline P. florida & 39.20 & 22.85 & 38.80 & $33.61 \mathrm{bc}$ \\
\hline P. sajor caju & 18.61 & 48.39 & 17.43 & $28.14 \mathrm{~d}$ \\
\hline P. ulmarius & 41.71 & 30.50 & 43.65 & $38.62 \mathrm{a}$ \\
\hline P. flabellatus & 40.02 & 29.44 & 38.61 & $36.02 \mathrm{ab}$ \\
\hline P. fossilatus & 43.84 & 30.82 & 40.68 & $38.45 \mathrm{a}$ \\
\hline Mean & $36.51 \mathrm{a}$ & $30.17 \mathrm{~b}$ & $36.94 \mathrm{a}$ & \\
\hline
\end{tabular}

\section{C.V $=14.07$}

\begin{tabular}{|c|c|c|c|}
\hline & SE & SEm & CD@ 5\% \\
\hline Species & 1.77 & 1.25 & 3.52 \\
\hline Season & 1.25 & 0.88 & 2.48 \\
\hline Species X Season & 3.07 & 2.17 & 6.11 \\
\hline
\end{tabular}

\begin{tabular}{|c|c|c|c|c|}
\hline \multirow{2}{*}{ Species } & \multicolumn{4}{|c|}{ Average weight of a single fruit body (gms) } \\
\cline { 2 - 5 } & Spring & Summer & Autumn & Mean \\
\hline P. petaloides & 4.01 & 3.49 & 3.49 & $3.66 \mathrm{e}$ \\
\hline P. florida & 5.97 & 5.88 & 6.01 & $5.95 \mathrm{~d}$ \\
\hline P. sajor caju & 7.86 & 9.40 & 7.97 & $8.41 \mathrm{a}$ \\
\hline P. ulmarius & 7.13 & 6.80 & 7.18 & $7.04 \mathrm{c}$ \\
\hline P. flabellatus & 5.93 & 6.31 & 6.00 & $6.08 \mathrm{~d}$ \\
\hline P. fossilatus & 8.12 & 7.82 & 7.39 & $7.78 \mathrm{~b}$ \\
\hline Mean & 6.50 & 6.62 & 6.34 & \\
\hline
\end{tabular}

*Means followed by similar letters are statistically identical

C.V $=\mathbf{1 7 . 7 0}$

\begin{tabular}{|c|c|c|c|}
\hline & SE & SEm & CD@ 5\% \\
\hline Species & $\mathbf{0 . 4 2}$ & $\mathbf{0 . 2 9}$ & $\mathbf{0 . 8 3}$ \\
\hline Season & $\mathbf{0 . 2 9}$ & $\mathbf{0 . 2 1}$ & NS \\
\hline Species X Season & $\mathbf{0 . 7 3}$ & $\mathbf{0 . 5 1}$ & NS \\
\hline
\end{tabular}

*Means followed by similar letters are statistically identical 


\begin{tabular}{|c|c|c|c|c|}
\hline \multirow{2}{*}{ Species } & \multicolumn{4}{|c|}{ Average number of fruit bodies per kg mushroom } \\
\cline { 2 - 5 } & Spring & Summer & Autumn & Mean \\
\hline P.petaloides & & 293.80 & 296.0 & $286.0 \mathrm{c}$ \\
\hline P. florida & 175.40 & 176.20 & 173.20 & $174.93 \mathrm{~b}$ \\
\hline P. sajor caju & 130.60 & 111.60 & 125.60 & $122.60 \mathrm{a}$ \\
\hline P. ulmarius & 143.20 & 147.80 & 143.80 & $144.93 \mathrm{a}$ \\
\hline P. flabellatus & 176.80 & 163.20 & 168.80 & $138.60 \mathrm{~b}$ \\
\hline P. fossilatus & 141.80 & 134.40 & 138.40 & \\
\hline Mean & 167.09 & 171.16 & 174.30 & \\
\hline
\end{tabular}

\begin{tabular}{|c|c|c|c|}
\hline & SE & SEm & CD@5\% \\
\hline Species & 11.49 & 8.13 & 22.86 \\
\hline Season & 8.13 & 5.74 & NS \\
\hline Species X Season & 19.91 & 14.08 & NS \\
\hline
\end{tabular}

*Means followed by similar letters are statistically identical

According to Hassan et al., (2010), variations in season seriously affected the number, weight and crop production period of mushroom. Maximum number of fruit body was recorded in autumn season. Favorable temperature and moisture conditions during autumn season enhanced the production of fruiting bodies of mushroom and maximum average weight of fruiting body was found in summer season. During this period fungal infection and insect infestation were relatively less that is why it is supposed that production rate was enhanced.

\section{References}

Amin, S. M. R., Sarker, N. C., Moonmoon, M., Khandaker, J. and M. Rahman. 2007. Officer's Training Manual. (National Mushroom Development and Extension Centre, Savar, Dhaka, Bangladesh) pp. 7-17.

Bano, Z. and Rajarathnam, S. 1982.
Mushroom J. 115, 243.

Hassan Sher., Mohammad.A. Y., Bakhli, A.M.A and Hazrat Sher. 2010. Effect of environmental factors on yield of selected mushroom species growing in two different agro ecological zones of Pakistan. Saudi Journal of Biological sciences. 17: 321-326.

Khan.A., Amin, S. M. R., Uddin, M. N., Tania, $\mathrm{M}$ and Alam, N. 2008. Bangladesh J. Mushroom, 2, 9

Kong, W. S. 2004. Oyster mushroom cultivation, In: Mushroom Growers'. pp. 54-57.

Sarker, N. C., Hossain, M. M., Sultana, N., Mian, I. H., Karim, A. J. M. S. and Amin, S. M. R. 2008. Bangladesh J. Mushroom, 2, 27.

Van Peer, A. F., Muller, W. H., Boekhout, T., Lugones, L. G and Wosten, H. A. 2009. PLoS One 4, e5977. doi: 10.1371/ journal.pone.0005977.

\section{How to cite this article:}

Shaheen Kouser, Farahanaz Rasool, Nighat Mushtaq and Rehana Jan. 2017. Evaluation of Different Species of Pleurotus for Maximum Yield in Different Seasons on Paddy Straw under Temperate Conditions of Kashmir Valley. Int.J.Curr.Microbiol.App.Sci. 6(12): 1202-1205. doi: https://doi.org/10.20546/ijcmas.2017.612.136 